\title{
ANALISIS FAKTOR-FAKTOR YANG MEMPENGARUHI MINAT MAHASISWA AKUNTANSI UNTUK MENGIKUTI PENDIDIKAN PROFESI AKUNTANSI DITINJAU DARI GENDER DAN STATUS AKREDITASI PROGRAM STUDI
}

\begin{abstract}
The purpose of this research to analyze the influence of career motivation, motivational qualities, economic motivation, motivation degree, the motivation to follow Certification Exam Certified Public Accountants, the cost of education and a long interest in the education of accounting students to follow the Accounting Profession. Population in this research that students majoring in accounting at a private college in Semarang, purposive sampling technique used for sample retrieval and obtained a sample of 50 respondents, the data analysis techniques used multiple linear regression

These results indicate that the economic motivation, motivation and motivation to follow quality Certification Exam Certified Public Accountants significantly influence accounting students' interest to follow Accounting Profession. Career motivation, degree of motivation, education costs and length of education did not significantly affect student interest in accounting to follow the Accounting Profession. Other results showed that no significant differences in student interest in accounting to follow the Accounting Profession in terms of gender, and there is also no significant difference in student interest in accounting to follow the Accounting Profession in terms of accreditation status
\end{abstract}

Keywords: motivation, gender, accredition, Accounting Profession.

\section{PENDAHILUAN}

Seorang sarjana lulusan akuntansi dituntut untuk lebih profesional pada era globalisasi saat ini. Hal ini disebabkan adanya tuntutan dari dunia bisnis dan ekonomi yang semakin meningkat. Perkembangan profesi akuntan mempunyai hubungan erat dengan tata nilai dan budaya yang berkembang di tengah masyarakat. Hal ini mengakibatkan profesi akuntan tidak bisa lepas dari perkembangan yang terjadi di negeri ini. Oleh karena itu, profesi akuntan dituntut untuk dapat menjawab tantangan yang ditimbulkan oleh perubahan lingkungan. Konsekuensi dari adanya perubahan lingkungan dan perkembangan dunia usaha pada dasarnya menuntut peningkatan kualitas diri dari akuntan dalam memberikan jasa profesionalnya.

Mahasiswa yang mengikuti Pendidikan Profesi Akuntansi (PPAk) adalah calon akuntan yang nantinya berhak mengikuti Ujian Sertifikasi Akuntan Publik (USAP). Ujian ini merupakan syarat penting untuk mendapatkan ijin praktik sebagai akuntan publik. Dengan mengikuti ujian ini, diharapakan calon akuntan di masa depan tidak hanya mahir secara teknis namun juga mahir secara profesional. Dengan demikian, lulusan PPAk nantinya akan memiliki daya saing sebagai akuntan yang lebih tinggi dibandingkan dengan sarjana ekonomi dari jurusan akuntansi yang tidak mempunyai predikat akuntan.

Pendidikan Profesi Akuntansi (PPAk) di Indonesia mulai berdiri sejak September 2002. Adanya PPAk ini 
maka pemberian gelar akuntan bukan lagi monopoli Perguruan Tinggi Negeri (PTN) tertentu yang diberi hak istimewa oleh Depdiknas akan tetapi tidak menutup kemungkinan PPAk diselenggarakan oleh Perguruan Tinggi Swasta (PTS) yang memiliki kesetaraan dengan Perguruan Tinggi Negeri. Dengan demikian diharapkan para akuntan di masa akan datang, khususnya dalam era globalisasi ekonomi abad 21, akan menjadi akuntan yang profesional dan siap menghadapi persaingan di tingkat global.

Widyastuti, dkk (2004) menyatakan bahwa motivasi karir merupakan faktor yang paling signifikan mempengaruhi minat mahasiswa untuk mengikuti PPAk, sedangkan motivasi kualitas dan motivasi ekonomi tidak signifikan. Suranta dan Syafiqurrahman (2006) menyatakan bahwa motivasi karir dan motivasi kualitas berpengaruh signifikan terhadap minat mahasiswa untuk mengikuti PPAk, sedangkan motivasi ekonomi tidak berpengaruh signifikan terhadap minat mahasiswa untuk mengikuti PPAk.

Gender dalam kebudayaan timur merupakan faktor yang erat hubungannya dalam karir dengan batasan wanita untuk beraktivitas. Pandangan masyarakat luas, status wanita umumnya dianggap lebih rendah dari pria. Peran wanita dalam berkarir dihalangi oleh persoalan budaya dan kodrat wanita yang menuntut peranan yang lebih dalam rumah tangga dibandingkan dalam bekerja. Wanita juga sering kali kurang mendapat kesempatan dan penghasilan yang sama dikarenakan adanya kesalahan persepsi terhadap kemampuan mereka (Ancok, 1995). Penelitian yang dilakukan Sudaryono, dkk (2005) menyatakan bahwa tidak ada perbedaan yang signifikan minat mahasiswa akuntansi dalam mengikuti PPAk ditinjau dari segi gender. Hasil ini didukung oleh penelitian yang dilakukan Machfoedz (1998) yang menyatakan bahwa minat mahasiswa mengikuti USAP tidak dipengaruhi oleh gender.

Setiap Perguruan Tinggi atau bahkan setiap program studinya memiliki status akreditasi yang tidak sama. Baik itu untuk Perguruan Tinggi Negeri maupun Perguruan Tinggi Swasta. Penelitian yang dilakukan Sudaryono, dkk (2005) menyatakan bahwa tidak ada perbedaan minat yang signifikan antara mahasiswa yang berasal dari program studi yang terakreditasi A dan B. Sedangkan perbedaan minat mengikuti PPAk terjadi antara mahasiswa yang berasal dari program studi yang terakreditas $A$ dan $C$, dan juga antara mahasiswa yang berasal dari program studi yang terakeditasi B dan C.

Dengan menjadikan penelitian sebelumnya yang telah dilakukan oleh Benny dan Yuskar (2006) sebagai acuan, penelitian ini akan mencoba merumuskan mengenai faktor-faktor apa saja yang mempengaruhi minat mahasiswa akuntansi untuk mengikuti Pendidikan Profesi Akuntansi (PPAk) ditinjau dari gender dan status akreditasi program studi.

Lisnasari dan Fitriany (2008) melakukan penelitian untuk mengetahui faktor-faktoryang mempengaruhi minat mahasiswa akuntansi untuk mengikuti Pendidikan Profesi Akuntansi (PPAk) dengan analisis regresi linier berganda. Hasil yang didapat yaitu motivasi karier dan motivasi mengikuti USAP merupakan faktor yang secara signifikan mempengaruhi minat mahasiswa untuk mengikuti PPAk.

\section{TELAAH LITERATUR DAN PENGEMBANGAN HIPOTESIS}

\section{Motivasi Karir}

Motivasi adalah dorongan yang timbul pada diri seseorang, sadar atau tidak sadar untuk melakukan 
suatu tindakan dengan tujuan tertentu. Motivasi juga merupakan usaha-usaha yang dapat menyebabkan seseorang atau kelompok orang tertentu tergerak melakukan sesuatu karena ingin mencapai tujuan yang dikehendakinya atau mendapat kepuasan dengan perbuatannya (Kamus Besar Bahasa Indonesia,1998).

Widyastuti, dkk (2004) menyatakan bahwa motivasi seringkali diartikan sebagai dorongan. Dorongan atau tenaga tersebut merupakan gerak jiwa dan jasmani untuk berbuat, sehingga motivasi merupakan suatu tenaga yang menggerakkan manusia untuk bertingkah laku didalam perbuatannya yang mempunyai tujuan tertentu.

Hipotesis 1: Motivasi karir mempengaruhi minat mahasiswa akuntansi untuk mengikuti PPAk.

\section{Minat}

Minat adalah keinginan yang didorong oleh suatu keinginan setelah melihat, mengamati dan membandingkan serta mempertimbangkan dengan kebutuhan yang diinginkannya (Widyastuti, dkk, 2004). Minat juga dapat diartikan sebagai kecenderungan bertingkah laku yang terarah terhadap objek kegiatan atau pengalaman tertentu (Ensiklopedia Indonesia IV, 1998:2252). Secara garis besar minat adalah kecenderungan seseorang yang menunjukkan perhatian terhadap suatu subjek tertentu, dalam hal ini berhubungan dengan minat mengikuti Pendidikan Profesi Akuntansi (PPAk).

Hipotesis 2: Motivasi kualitas mempengaruhi minat mahasiswa akuntansi untuk mengikuti PPAk.

Hipotesis 3: Motivasi ekonomi mempengaruhi minat mahasiswa akuntansi untuk mengikuti PPAk.

\section{Profesi Akuntan}

Menurut International Federation of Accountants yang dimaksud profesi akuntan adalah semua bidang pekerjaan yang mempergunakan keahlian di bidang akuntansi, termasuk bidang pekerjaan akuntan publik, akuntan intern yang bekerja pada perusahaan industri, keuangan atau dagang, akuntan yang bekerja di pemerintah, dan akuntan sebagai pendidik.

Ciri yang sangat menonjol dari profesi adalah adanya pengakuan atas tanggung jawabnya kepada masyarakat. Bagi profesi akuntansi (para akuntan), IFAC mengidentifikasikan ruang lingkup masyarakat yang menjadi tanggung jawab akuntan meliputi: klien, kreditur, perusahan pemberi jasa, karyawan, investor, pemerintah, masyarakat keuangan dan dunia usaha pada umumnya.

Hipotesis 4: Motivasi gelar mempengaruhi minat mahasiswa akuntansi untuk mengikuti PPAk.

\section{Ujian Sertifikasi Akuntan Publik (USAP)}

Ujian Sertifikasi Akuntan Publik (USAP) adalah ujian yang harus diikuti oleh semua sarjana jurusan akuntansi yang ingin memperoleh atau menyandang sebutan akuntan publik. USAP dilaksanakan berdasarkan Keputusan Menteri Keuangan RI No. 43/KMK.017/1997 tertanggal 27 Januari 1997. Ujian Sertifikasi Akuntan Publik (USAP) merupakan strategi pengembangan profesi akuntan di Indonesia menghadapi era perdagangan bebas.

Akuntan yang telah lulus USAP akan memperoleh sebutan "Bersertifikat Akuntan Publik (BAP)". Sertifikat 
BAP dikeluarkan oleh Ikatan Akuntan Indonesia (IAI). Akuntan dengan sebutan BAP akan memperoleh pengakuan atas kompetensi dalam bidang akuntansi keuangan, auditing, dan bidang-bidang terkait seperti perpajakan dan sistem informasi. Dengan demikian diharapkan akuntan publik BAP mempunyai kualifikasi sebagai akuntan publik yang handal dalam menghadapi persaingan di pasar global. Oleh karena itu, dapat dihipotesiskan sebagai berikut:

Hipotesis 5: Motivasi mengikuti USAP mempengaruhi minat mahasiswa akuntansi untuk mengikuti PPAk.

\section{Pendidikan Profesi Akuntansi (PPAk)}

Keputusan Mendiknas Nomor 179/U/2001 menyebutkan Pendidikan Profesi Akuntansi adalah pendidikan tambahan pada pendidikan tinggi setelah program sarjana IImu Ekonomi pada program studi akuntansi. Pendidikan profesi akuntansi bertujuan menghasilkan lulusan yang menguasai keahlian bidang profesi akuntansi dan memberikan kompensasi keprofesian akuntansi. Lulusan Pendidikan Profesi Akuntansi berhak menyandang sebutan gelar profesi akuntan yang selanjutnya disingkat Ak.

Pendidikan profesi akuntansi yang menghasilkan akuntan dari perguruan tinggi merupakan produk hasil proses belajar mengajar. Salah satu indikator peningkatan profesionalisme adalah adanya kurikulum yang memadai dan adanya standar profesionalisme melalui ujian profesi. Seorang akuntan harus memperhatikan standar teknik profesi dan etika serta berupaya terus untuk meningkatkan kemampuan. Machfoedz (1998) mengemukakan bahwa profesionalisme ditandai dengan adanya tiga indikator, yaitu Pengetahuan (knowledge), Keterampilan (skill), dan Etika.

Hipotesis 6: Biaya pendidikan mempengaruhi minat mahasiswa akuntansi untuk mengikuti PPAk.

Hipotesis 7: Lama pendidikan PPAk mempengaruhi minat mahasiswa akuntansi untuk mengikuti PPAk.

\section{Gender}

Pengertian gender menurut Fakih (1996) adalah suatu sifat yang melekat pada kaum laki-laki maupun perempuan yang dikonstruksi secara sosial maupun kultural. Sedang menurut Squire dalam Suhapti (1995) gender adalah perbedaan peran antara perempuan dan laki-laki yang mengakibatkan perbedaan perlakuan antara perempuan dan laki-laki di masyarakat. Palupi dan Setiawan (2003) menunjukkan bahwa ada perbedaan etika antara akuntan pendidik laki-laki dan wanita dalam hal keadilan, relativism, dan utilitarianism. Oleh karena itu, dapat dirumuskan hipotesis sebagai berikut:

Hipotesis 8: Tidak ada perbedaan yang signifikan pada minat mahasiswa akuntansi dalam mengikuti PPAk ditinjau dari gender.

Hipotesis 9: Tidak ada perbedaan yang signifikan pada minat mahasiswa akuntansi dalam mengikuti PPAk ditinjau dari status akreditasi program studi

\section{METODE PENELITIAN}

Populasi dari penelitian ini adalah mahasiswa jurusan akuntansi pada perguruan tinggi swasta di Semarang. Teknik pengambilan sampel dilakukan melalui teknik purposive sampling, yaitu teknik pengambilan sampel 
berdasarkan kriteria tertentu. Kriteria sampel yaitu: Mahasiswa akuntansi di Perguruan Tinggi Swasta yang memiliki status akreditasi program studi A dan B. Mahasiswa akuntansi semester 7.

Teknik pengumpulan data menggunakan kuesioner, yaitu dengan membagikan kuesioner kepada responden langsung untuk meyakinkan bahwa kuesioner sampai pada responden yang diinginkan dan responden merasa dihargai sehingga mengisi kuesioner dengan lengkap dan jujur. Data yang diperoleh berupa jawaban kuesioner yang dapat menggambarkan kinerja responden.

\section{HASIL DAN PEMBAHASAN}

\section{Statistik Deskiptif}

Sampel yang diperoleh dengan teknik pengambilan sampel purposive sampling adalah sebanyak 50 responden, yaitu dari UNISSULA dan UDINUS yang mewakili akreditasi A dan akreditasi B. Berikut ini hasil analisis statistik deskriptif, variabel motivasi karir memiliki rata-rata (mean) sebesar 43,16 dan standar deviasi 4,460. Variabel motivasi kualitas memiliki rata-rata (mean) sebesar 41,82 dan standar deviasi 4,552. Variabel motivasi ekonomi memiliki rata-rata (mean) sebesar 43,88 dan standar deviasi 4,955. Variabel motivasi gelar memiliki rata-rata (mean) sebesar 4,34 dan standar deviasi 0,798. Variabel motivasi mengikuti USAP memiliki rata-rata (mean) sebesar 4,04 dan standar deviasi 0,755. Variabel biaya pendidikan memiliki rata-rata (mean) sebesar 3,80 dan standar deviasi 0,857. Variabel lama pendidikan memiliki rata-rata (mean) sebesar 3,20 dan standar deviasi 1,030. Variabel minat mengikuti PPAk memiliki rata-rata (mean) sebesar 19,80 dan standar deviasi 3,097.

\section{Pengujian Hipotesis}

Motivasi karir tidak mempunyai pengaruh yang signifikan terhadap minat mahasiswa akuntansi untuk mengikuti PPAk, hal ini dibuktikan dengan signifikansi 0,132 >0,05. Kondisi ini terjadi karena dari hasil penelitian, responden atau mahasiswa yang diteliti menganggap bahwa motivasi karir bukan faktor yang mempengaruhi minat mahasiswa mengikuti PPAk. Suatu perusahaan dalam mencari calon karyawan tidak mengharuskan seseorang memiliki gelar akuntan ataupun beregister. Hanya perusahaan tertentu saja, seperti BUMN yang menuntut calon pegawainya memiliki gelar akuntan, sehingga motivasi karir tidak berpengaruh terhadap minat mahasiswa mengikuti PPAk.

Motivasi kualitas mempunyai pengaruh yang signifikan terhadap minat mahasiswa akuntansi untuk mengikuti PPAk, hal ini dibuktikan dengan signiifkasi 0,017<0,05. Kondisi ini terjadi karena mahasiswa berkeinginan untuk meningkatkan kualitas diri, sehingga bisa menghadapai persaingan dunia kerja yang semakin kompetitif. Secara teori motivasi kualitas sebagai dorongan yang timbul dalam diri seseorang untuk memiliki dan meningkatkan kualitas diri dan kemampuannya dalam bidang yang ditekuninya sehingga dapat melaksanakan tugas dengan baik dan benar.

Motivasi ekonomi mempunyai pengaruh yang signifikan terhadap minat mahasiswa akuntansi untuk mengikuti PPAk, hal ini dibuktikan dengan signifikansi 0,029 <0,05. Kondisi ini terjadi karena mahasiswa menginginkan kerja keras mengikuti PPAk bisa menambah nilai tambah yang besifat ekonomis, karena 
pada jaman sekarang faktor ekonomi menjadi sangat penting dalam kehidupan sehari-hari. Secara teoritis penghargaan finansial merupakan salah satu bentuk sistem pengendalian manajemen. Untuk memastikan bahwa elemen karyawan dapat mengarahkan tindakannya terhadap pencapaian tujuan perusahaan, maka manajemen memberikan balas jasa atau reward dalam berbagai bentuk, termasuk di dalamnya financial reward atau penghargaan finansial.

Motivasi gelar tidak mempunyai pengaruh yang signifikan terhadap minat mahasiswa akuntansi untuk mengikuti PPAk, hal ini dibuktikan dengan signifikansi 0,553 $>0,05$. Kondisi ini terjadi karena pendidikan Akt tidak menunjukkan jenjang pendidikan yang lebih tinggi. Gelar Akt lebih menunjukkan kualifikasi dan spesifikasi seseorang yang berprofesi di bidang akuntansi dibandingkan dengan sesorang lulusan S1 akuntansi yang bergelar SE.

Motivasi mengikuti USAP mempunyai pengaruh yang signifikan terhadap minat mahasiswa akuntansi untuk mengikuti PPAk, hal ini dibuktikan dengan signifikansi 0,001 $<0,05$. Kondisi ini terjadi karena USAP merupakan suatu ujian profesi yang berfungsi sebagai sebuah sistem saringan yang baku bagi mereka yang akan berpraktik sebagai Akuntan Publik. Akuntan yang telah lulus untuk semua mata ujian berhak memperoleh sebutan "Bersertifikasi Akuntan Publik (BAP). Setifikat akuntan publik merupakan salah satu persyaratan utama untuk mendapatkan izin praktek. USAP hanya diikuti oleh mereka yang memiliki gelar akuntan yang hanya diperoleh setelah menempuh PPAk.

Biaya pendidikan tidak mempunyai pengaruh yang signifikan terhadap minat mahasiswa akuntansi untuk mengikuti PPAk, hal ini dibuktikan dengan signifikansi 0,158 $>0,05$. Kondisi ini terjadi karena bagi mahasiswa untuk memperoleh gelar akuntan, dengan biaya pendidikan berapapun tidak menjadi masalah, sehingga mereka tetap mengikuti PPAk. Hal tersebut dikarenakan mahasiswa ingin meningkatkan kualitas atau kemampuan di bidang akuntansi.

Lama pendidikan tidak mempunyai pengaruh yang signifikan terhadap minat mahasiswa akuntansi untuk mengikuti PPAk, hal ini dibuktikan dengan signifikansi 0,244>0,05. Kondisi ini terjadi karena pendidikan profesi akuntansi hanya ditempuh dalam kurun waktu 1 tahun, sehingga untuk menempuh pendidikan tersebut tidak terasa lama. Apabila mahasiswa yang sudah bekerja ingin mengikuti PPAk, hal tersebut masih bisa dilakukan, karena ada pendidikan profesi akuntansi yang membuka kelas malam.

Minat mahasiswa akuntansi untuk mengikuti PPAk ditinjau dari gender tidak menunjukkan perbedaan yang signifikan. Kondisi ini terjadi karena mahasiswa laki-laki dan perempuan mempunyai minat yang sama mengikuti PPAk. Di era globalisasi gender bukan menjadi masalah, sebab antara laki-laki dan perempuan memiliki kesamaan kesempatan untuk berkembang dan maju.

Minat mahasiswa akuntansi untuk mengikuti PPAk ditinjau dari status akreditasi program studi tidak menunjukkan perbedaan yang signifikan. Kondisi ini terjadi karena setiap perguruan tinggi atau program studi memiliki akreditasi yang berbeda. Status akreditasi A dan B tidak jauh berbeda, karena untuk mengikuti PPAk mahasiswa tidak memandang status akreditasi program studi, baik itu A maupun B. Sedangkan yang berbeda adalah akreditasi A dan C. 


\section{SIMPULAN, KETERBATASAN DAN SARAN}

Berdasarkan hasil penelitian dan pembahasan di atas, maka dapat ditarik kesimpulan sebagai berikut : pertama, Tidak ada pengaruh antara motivasi karir terhadap minat mahasiswa akuntansi untuk mengikuti pendidikan profesi akuntansi. Kedua, Ada pengaruh antara motivasi kualitas terhadap minat mahasiswa akuntansi untuk mengikuti pendidikan profesi akuntansi. Ketiga, Ada pengaruh antara motivasi ekonomi terhadap minat mahasiswa akuntansi untuk mengikuti pendidikan profesi akuntansi. Keempat, Tidak ada pengaruh antara motivasi gelar terhadap minat mahasiswa akuntansi untuk mengikuti pendidikan profesi akuntansi. Kelima, Ada pengaruh antara motivasi mengikuti USAP terhadap minat mahasiswa akuntansi untuk mengikuti pendidikan profesi akuntansi. Keenam, Tidak ada pengaruh antara biaya pendidikan terhadap minat mahasiswa akuntansi untuk mengikuti pendidikan profesi akuntansi. Ketujuh, Tidak ada pengaruh antara lama pendidikan terhadap minat mahasiswa akuntansi untuk mengikuti pendidikan profesi akuntansi. Kedelapan, Tidak ada perbedaan yang signifikan minat mahasiswa akuntansi untuk mengikuti PPAk ditinjau dari gender. Kesembilan, Tidak ada perbedaan yang signifikan minat mahasiswa akuntansi untuk mengikuti PPAk ditinjau dari status akreditasi program studi.

Keterbatasan dalam penelitian ini adalah:Lingkup penelitian ini hanya 2 Perguruan Tinggi Swasta (Unissula dan Udinus), sehingga penelitian selanjutnya sebaiknya menggunakan lebih dari 2 Perguruan Tinggi, sehingga bisa membandingkan antara status akreditasi A dan C. Penelitian ini dilakukan di lingkup kota Semarang dengan sampel sebanyak 50 responden, untuk penelitian selanjutnya bisa menambah jumlah responden dengan memperluas daerah penelitian misalnya Yogyakarta, Bandung atau Jakarta. Variabel motivasi gelar, motivasi mengikuti USAP, biaya pendidikan dan lama pendidikan hanya terdiri dari 1 indikator saja, sebaiknya untuk penelitian selanjutnya ditambah beberapa indikator lagi.

\section{DAFTAR PUSTAKA}

Ancok, D. 1995. Nuansa Psikologi Pembangunan. Pustaka Pelajar, Yogyakarta.

Benny dan Yuskar. 2006. "Pengaruh Motivasi terhadap Minat Mahasiswa Akuntansi Untuk Mengikuti Pendidikan Profesi Akuntansi (PPAk)". Simposium Nasional Akuntansi IX.

Fakih, M. 1999. Gender dan Perubahan Organisasi. Pustaka Pelajar, Yogyakarta.

Lisnasari dan Fitriany, 2008. “Faktor-Faktor yang Mempengaruhi Minat Mahasiswa Akuntansi Untuk Mengikuti Pendidikan Profesi Akuntansi (Studi empiris di Universitas Indonesia)". The 2nd Accounting Conference, 1st Doctoral Colloquium, and Accounting Workshop Depok.

Machfoedz, M. 1998. "Survey Minat Mahasiswa Untuk Mengikuti Ujian Sertifikasi Akuntan Publik (USAP)". Jurnal Ekonomi dan Bisnis Indonesia, Volume 13 No.4.

IAI, Penegakan Etika Profesi Upaya Menciptakan Akuntan yang Profesional. Media Akuntansi, 28 September 2002.

Palupi dan Setiawan. 2003. "Pengaruh Perbedaan Gender terhadap Etika Akuntan Pendidik". Working paper jurusan akuntansi, Fakultas Ekonomi, Universitas Sebelas Maret.

Suranta dan Syafiqurrahman, 2006.“Pengaruh Motivasi terhadap Minat Mahasiswa Untuk Mengikuti Pendidikan 


\section{JURNAL AKUNTANSI INDONESIA}

Profesi Akuntansi di Karesidenan Surakarta". Jurnal Empirika, Volume 19 No.1, Juni 2006.

Sudaryono, dkk. 2005. "Minat Mahasiswa Akuntansi dalam Mengikuti Pendidikan Profesi Akuntansi (PPA) Ditinjau dari Gender dan Status Akreditasi Program Studi". Jurnal Akuntansi dan Investasi. Vol. 6 No.2, Juli 2005.

Suhapti, R. 1995. Gender dan Permasalahannya. Buletin Psikologi, tahun III, No.1.

Undang-Undang Nomor 34 tahun 1954 Tentang Pemakaian Gelar Akuntan.

Widyastuti, dkk. 2004. "Pengaruh Motivasi terhadap Minat Mahasiswa Akuntansi Untuk Mengikuti Pendidikan Profesi Akuntansi". Simposium Nasional Akuntansi VII.

Jurnal Akuntansi Indonesia 
Lampiran

Tabel 1

Hasil Regresi Berganda

\begin{tabular}{|c|c|c|c|c|c|c|}
\hline \multicolumn{7}{|c|}{ Coefficients $^{a}$} \\
\hline & & \multicolumn{2}{|c|}{ Unstandardized } & Standardized & & \\
\hline 1 & (Constant) & .896 & 4.415 & & .203 & .840 \\
\hline & Motivasi karir & -.148 & .096 & -.213 & -1.535 & .132 \\
\hline & motivasi kualitas & .310 & .110 & .333 & 2.820 & .017 \\
\hline & motivasi ekonomi & .169 & .075 & .270 & 2.266 & .029 \\
\hline & motivasi gelar & .307 & .512 & .079 & .599 & .553 \\
\hline & motivasi mengikuti USAP & 2.220 & .602 & .441 & 3.685 & .001 \\
\hline & biaya pendidikan & .654 & .455 & .181 & 1.437 & .158 \\
\hline & lama pendidikan & .412 & .349 & .137 & 1.181 & .244 \\
\hline
\end{tabular}

a. 
